Research Article

\title{
The Prevalence of Occupational Injuries and Associated Risk Factors among Workers in Bahir Dar Textile Share Company, Amhara Region, Northwest Ethiopia
}

\author{
Destaw Damtie (iD ${ }^{1}$ and Abraraw Siraj ${ }^{2}$ \\ ${ }^{1}$ Bahir Dar University, College of Sciences, Department of Biology, Bahir Dar, Ethiopia \\ ${ }^{2}$ Ghion Preparatory School, Bahir Dar, Ethiopia \\ Correspondence should be addressed to Destaw Damtie; zegades96@gmail.com
}

Received 6 March 2020; Revised 21 May 2020; Accepted 12 June 2020; Published 24 July 2020

Academic Editor: Issam A. Al-Khatib

Copyright (c) 2020 Destaw Damtie and Abraraw Siraj. This is an open access article distributed under the Creative Commons Attribution License, which permits unrestricted use, distribution, and reproduction in any medium, provided the original work is properly cited.

\begin{abstract}
Introduction. Occupational injuries are occurrences arising out of, or in the course of, work which results in a fatal or nonfatal injury, e.g., a fall from a height or contact with moving machines. They pose psychological, behavioral, social, vocational, and economic problems. No previous studies have been conducted on the prevalence and associated risk factors of occupational injuries among workers in Bahir Dar Textile Share Company (SC). Therefore, this study aimed to assess the prevalence and associated risk factors of occupational injury in Bahir Dar Textile SC, Northwest Ethiopia. Methods. A cross-sectional study was conducted among employees of Bahir Dar Textile SC in 2019. Three hundred (195 males and 105 females) employees were selected using proportional simple random sampling from the spinning, weaving, finishing, engineering, and administration sections. Results. The one-year and the two-week occupational injury prevalences were $42.7 \%$ and $6.7 \%$, respectively. The one-year report from all the respondents shows that abrasion $(10.7 \%)$ and eye injury $(7.7 \%)$ were the two top injuries, hands $(12.7 \%)$ and eyes (7.7\%) were the top injured body parts, and machines (22.7\%) and falling/slipping (6.3\%) caused most injuries. Statistically significant differences in injuries $(p<0.05)$ were observed due to variations in gender, job category, exposure to vibration, exposure to rays/welding sparks, and labor-intensive work. The weaving section was positively associated with occupational injuries at $\mathrm{AOR}=4.497$ and $p=0.05$. Conclusions. Occupational injuries prevalence is high over the last year. The major causes of injuries were machines and falling/slipping, while the major injuries were abrasions, eye injuries, sprains, and burns. The factors significantly associated with occupational injuries were male gender, job category, use of vibrating tools, high intensive work, and rays/welding sparks. Occupational safety and health training, use of personal protective equipment (PPE), and shifting employees from intensive works are recommended.
\end{abstract}

\section{Introduction}

Ethiopia is applying the second growth and transformation plan (GTP II) to bring economic transformation and accelerated growth towards the realization of the national vision to become a low middle-income country by 2025 . The GTP II aimed to raise the textile and garment industry by $80 \%$ by the end of the plan period (2019/20). Accordingly, it is planned to manufacture USD 2.18 billion and earn USD 779 million in revenue from this sector. The sector will create 174,000 job opportunities and reduce carbon emission by $25 \%$ [1].
Occupational injuries are epidemic problems in the field of public health in developing countries [2]. This is mainly because the focus on occupational health and safety, including the prevention of occupational injuries, is very limited in low-income countries [3]. For example, in a review of articles published from low-income countries especially from the East African area, the total rate of significant injuries is estimated at 40,000 per 100,000 workers per year [4]. Millions of injury cases occur every year globally [5]. In 2014, the numbers of global fatal and nonfatal occupational accidents were 381 thousand and 374 
million, respectively [6]. In Ethiopia, the one-year prevalence of occupational injuries was $31.4 \%$ among workers in the Arba Minch textile factory [7], 36.9\% among workers of Kombolcha textile factory [8], and $40.8 \%$ among workers of Ayka Addis textile factory [9].

These occupational injuries were associated with different risk factors: age ( $<30$ years), male gender, health and safety training, sleeping disturbance, and job stress [10]; extra hour duty, health and safety training, workplace supervision, personal protective equipment use, and job stress in Arba Minch textile factory [7]; sex, service year and ventilation of working unit in textile factory workers in Northwest Ethiopia [11]; PPE use and sleeping disorder among workers of Ayka Addis textile factory [9]; working $>48 \mathrm{hrs} / \mathrm{wk}$, handling objects, visual concentration, timely maintenance of the machine, and sleep disorder in Kombolcha textile factory [12].

Occupational injuries pose psychological, behavioral, social, vocational, and economic problems on the employee, employer, and society [3, 13, 14]. According to the 2017 International Labor Organization (ILO) estimates, the global and African gross domestic product (GDP) losses due to occupational accidents and work-related diseases were $3.94 \%$ and $4 \%$, respectively [15].

The authors of the present study, thus, were interested to examine the one-year [10] occupational injuries and associated risk factors among workers in Bahir Dar Textile SC. Bahir Dar Textile SC was founded in 1961 by the Italian government grant to Ethiopia as a war compensation [16]. It is the largest factory in the Amhara region and close to Bahir Dar University. It creates job opportunities for a lot of employees and has a big share in the country's economy. Since 2013, the company gave priority to the international market and exports its products to western countries. It manufactures yarn produced in the open-end and ring line, quilt cover, pillowcase, flat sheet, gray fabric, died/printed sheets, and other home textile products [17].

In Ethiopia, industrial production is growing (10.5\%) and incorporates $7.4 \%$ of the labor force and contributes to $27.26 \%$ of the GDP [18]. Occupational injuries, thus, may affect the labor force and the country's economy as well as GTP II goals $[1,19]$. No studies on occupational injuries and their associated factors have been conducted in Bahir Dar Textile SC. Furthermore, findings from studies in this factory can apply to other factories in Ethiopia. Therefore, the present study aimed to assess the one-year and two-week [7] prevalence and associated risk factors of occupational injury in Bahir Dar Textile SC, Northwest Ethiopia. It will provide information to the company to take injury prevention measures; to the country to make appropriate policies; to the workers to take caution.

\section{Materials and Methods}

2.1. Study Design. A cross-sectional study was conducted among employees of Bahir Dar Textile SC, Northwest Ethiopia, in 2019.
2.2. Study Setting. The study was conducted in Bahir Dar Textile SC. Bahir Dar Textile SC is found in Bahir Dar City, Northwest Ethiopia. It has 1373 workers (773 males and 600 females). All workers from spinning (224), weaving (245), finishing (292), engineering (296), and administration (316) sections were included as the study population. The shareholders of the company are the Ethiopian government and the Japanese group with a share of $65 / 35 \%$ shareholding, respectively [20]. The company utilizes organic cotton as the only raw material. The spinning section has the capacity of producing 15 tons of yarn per day. Weaving section has the capacity of producing 50-thousand-meter fabric, and the processing and finishing section can produce 82 thousand $\mathrm{m}^{2}$ of fabric per day. The garment section can produce 10 thousand pairs of bed sheets per day [17].

2.3. Participants. The source population was all workers from the four sections of the factory. Of these, those who had worked for at least one year $[7,10]$ before the study period and who were selected by proportional simple random sampling technique were included, while workers who were on sick, annual, maternity, and family leaves during the data collection and those who refused to give consent were excluded from the study.

2.4. Sampling Technique and Procedure. The sample size was calculated using a standard formula for a known population [21]. A 95\% probability of obtaining the population proportion of workers within a 5\% margin of error was assumed to be $50 \%$ as there was no data on the prevalence of occupational injuries and associated factors among workers in Bahir Dar Textile Share Company. The number of employees allocated in each section was based on the total number of employees in each section divided by the total number of employees of the company. The results were multiplied by the sample size. Finally, a total sample size of 300 (195 males and 105 females) were selected using proportional simple random sampling techniques by using the register as the sample frame.

2.5. Data Collection and Data Quality Control. Data were collected using a semistructured interviewer-administered questionnaire from 300 workers selected using proportional simple random sampling techniques. The questionnaires were prepared in English and translated to Amharic and back to the English language by independent experts to retain its consistency. The main contents of the questionnaire were sociodemographic characteristics (gender, age, religion, ethnicity, marital status, educational level, residence, job category, employment status, work experience, employment status, work experience, and monthly salary); environmental factors (noise, vibration, rays/welding sparks, workplace light, workplace temperature, chemical hazards, dusty work area, biological hazards, working by standing, labor-intensive work, and work supervision); behavioral factors (alcohol consumption, khat chewing, cigarette smoking, sleeping disturbance, job satisfaction, and PPE 
use). The data were collected by two nurses and two supervisors after two days of training following the training manual developed beforehand.

Before the actual data collection was conducted, a pretest was done in 5\% (25 workers) in Bahir Dar traditional weaver workers, and inputs from the pretest were used to modify the questionnaire more suitably to generate the desired data. The interview was conducted in a confidential setting and the interviewers were supervised at each site, and regular meetings were held between the data collectors, supervisors, and principal investigator. Moreover, consistency was checked before, during, and after entering the data into the computer.

\subsection{Operational Definitions}

(i) Occupational Injuries. They are personal injuries resulting from occupational accidents sustained on workers of Bahir Dar Textile SC in connection with the performance of their works in the past year [22].

(ii) Personal Protective Equipment (PPE). It includes goggles, helmet, face shield, gloves, boots, and specialized clothing that is designed to protect parts of the body including the eyes, face, hands, figure, and feet [23].

(iii) Job Satisfaction. It is any combination of psychological, physiological, and environmental circumstances that cause a person to truthfully say "I am satisfied with my job" [24].

(iv) Safety Training. OSH training is given to Bahir Dar Textile SC workers.

(v) Workplace Supervision. Regular supervisions are done by OSH responsible bodies in the working sections of the factory.

(vi) Working Section. It is one of the manufacturing units in Bahir Dar Textile SC.

(vii) Khat Chewing. It is the practice of chewing khat leaves by the worker at least once per week.

(viii) Cigarette Smoking. It is the regular inhalation of the gases and hydrocarbon vapors generated by slowly burning of cigarettes.

(ix) Sleeping Disturbance. It is the presence of sleeping problems when the worker is at work in the factory.

(x) Chemical Hazards. They include fumes, dust, and gases, especially from dyes.

(xi) Biological Hazards. They are organisms or organic substances that are harmful to the health of workers in Bahir Dar Textile SC. They include pests/parasites, viruses, bacteria, fungi/mold, and protein [25].

(xii) Labor-Intensive Work. This refers to a process or industry that requires a large amount of labor to produce its goods or services [26].

(xiii) Occupational Noise. Noise "so loud it required one to speak in a raised voice to be heard" and "at arm's length" as this vocal effort suggests noise exposures exceeding 85 to $90 \mathrm{dBA}$ [27].

2.7. Statistical Analysis. Statistical analysis was performed using statistical package for social sciences (SPSS) software version 23. Descriptive statistical methods, frequencies, and percentages were computed to summarize sociodemographic characteristics and injury prevalence of the workers. Bivariate and multivariate regressions were applied to explore the association between occupational injuries and associated risk factors at a $95 \%$ confidence interval (95\% CI). Only variables with $p$ values $\leq 0.25$ in the bivariate analysis were analyzed using multivariate logistic regression analysis.

2.8. Ethical Considerations. The study was conducted after appropriate ethical clearance was obtained from the Research Ethics Committee of the Science college of Bahir Dar University on $10^{\text {th }}$ April 2019. Informed written consent was also taken from each participant.

\section{Results}

3.1. Sociodemographic Characteristics. A total of 300 respondents (response rate $=100 \%$ ) participated in the study. One hundred ninety-five $(65.0 \%)$ of the participants were males. The participants aged 22-29 years old accounted for $69.3 \%$ of the study population, 293 (97.7\%) were Orthodox Christians, 297 (99.0\%) were ethnically Amharas, and 159 (53.0\%) were married. Two hundred twenty (73.3\%) participants had a higher education, 296 (98.7\%) were urban dwellers, 69 (23.0\%) were administrative staff, 296 (98.7\%) were permanent employees, 108 (36\%) earned monthly salary ranging from 2458 to 3941 Birr (72.81 to 116.74 USD), and $158(52.7 \%)$ had a working experience of less than five years (Table 1).

3.2. Prevalence of Occupational Injuries. The one-year and two-week prevalence of occupational injury were $42.7 \%$ (128) and 6.7\% (20), respectively. The most prevalent annual injuries were abrasion $(32 ; 10.7 \%)$ and eye injury $(23 ; 7.7 \%)$, and hands $(38 ; 12.7 \%)$ and eyes $(23 ; 7.7 \%)$ were the major body parts injured, and the main causes of injury were machines $(68 ; 22.2 \%)$ and falling/slipping $(19 ; 6.3 \%)$ (Table 2). Lack of PPEs (59; 19.7\%) and lack of safety training $(18 ; 6 \%)$ were the two top reasons for injury. Eighty-four (30\%) victims were hospitalized, and 926 working days were lost as a result of the 128 occupational injuries. Most injuries occurred on Monday and Friday, 14 (4.7\%) and 12 (4.0\%), respectively. Many of the injuries $(31 ; 10.3 \%)$ occurred in the afternoon (1:00 PM-6:00 PM) followed by those in the morning (28; 9.3\%) (7:00 AM-12:00 AM).

3.3. Association of the Prevalence of Occupational Injuries with Risk Factors. Results from the bivariate logistic regression (crude odds ratio $=$ COR) $($ Table 3 ) show that female workers were less likely to be injured compared with males $(\mathrm{COR}=0.421, p=0.001)$. The administrative staff were the 
TABLE 1: Sociodemographic characteristics of the respondents.

\begin{tabular}{|c|c|c|}
\hline Variables & Number & Percent \\
\hline \multicolumn{3}{|l|}{ Gender } \\
\hline Male & 195 & 65.0 \\
\hline Female & 105 & 35.0 \\
\hline \multicolumn{3}{|l|}{ Age } \\
\hline $22-29$ & 208 & 69.3 \\
\hline $30-34$ & 70 & 23.3 \\
\hline$>34$ & 22 & 7.3 \\
\hline \multicolumn{3}{|l|}{ Religion } \\
\hline Orthodox & 293 & 97.7 \\
\hline Muslim & 6 & 2.0 \\
\hline Protestant & 1 & 0.3 \\
\hline \multicolumn{3}{|l|}{ Ethnicity } \\
\hline Amharas & 297 & 99.0 \\
\hline Tigrayans & 2 & 0.7 \\
\hline Oromo & 1 & 0.3 \\
\hline \multicolumn{3}{|l|}{ Marital status } \\
\hline Married & 159 & 53.0 \\
\hline Single & 136 & 45.3 \\
\hline Divorced & 5 & 1.7 \\
\hline \multicolumn{3}{|l|}{ Education level } \\
\hline No education & 18 & 6.0 \\
\hline Primary & 13 & 4.3 \\
\hline Secondary & 49 & 16.3 \\
\hline Higher & 220 & 73.3 \\
\hline \multicolumn{3}{|l|}{ Residence } \\
\hline Urban & 296 & 98.7 \\
\hline Rural & 4 & 1.3 \\
\hline \multicolumn{3}{|l|}{ Job category } \\
\hline Spinning & 49 & 16.3 \\
\hline Weaving & 53 & 17.7 \\
\hline Engineering & 65 & 21.7 \\
\hline Finishing & 64 & 21.3 \\
\hline Administrative staff & 69 & 23.0 \\
\hline \multicolumn{3}{|l|}{ Employment status } \\
\hline Permanent & 296 & 98.7 \\
\hline Contract & 4 & 1.3 \\
\hline \multicolumn{3}{|l|}{ Work experience } \\
\hline$<5$ years & 158 & 52.7 \\
\hline$\geq 5$ years & 142 & 47.3 \\
\hline \multicolumn{3}{|l|}{ Monthly salary } \\
\hline$<2458$ birr $(<72.00$ USD $)$ & 41 & 13.7 \\
\hline 2459-3941 birr (72.03-115.45 USD) & 108 & 36.0 \\
\hline 3942-5776 birr (115.48-169.20 USD) & 98 & 32.7 \\
\hline$>5776$ birr (>169.20 USD) & 53 & 17.7 \\
\hline
\end{tabular}

least $(\mathrm{COR}=0.436, p=0.039)$ and workers from the weaving section were the highest $(\mathrm{COR}=4.556, p=0.001)$ injured.

Results from the multiple logistic regression (adjusted odds ratio $=\mathrm{AOR}$ ) also showed that female workers were less likely to face occupational injury compared with male workers $(\mathrm{AOR}=0.318, p=0.001)$. Weaving section workers had 4.497 times higher odds of occupational injury compared with workers of the spinning section $(\mathrm{AOR}=4.497$, $p=0.005)$. Workers who were not exposed to vibration were less likely to face occupational injury compared with workers who were exposed to vibration $(\mathrm{AOR}=0.419, p=0.021)$.
Workers who were not exposed to rays/welding sparks were less likely to face occupational injury compared with workers who were exposed to rays $(\mathrm{AOR}=0.366, p=0.012)$. Furthermore, workers who were not exposed to labor-intensive work had lower odds of occupational injury compared with workers who were exposed to labor-intensive work $(\mathrm{AOR}=0.343, p=0.003)$ (Table 3$)$.

\section{Discussion}

The one-year and two-week occupational injury prevalence was $42.7 \%$ (128) and $6.7 \%$ (20), respectively. This result agreed with the findings from Ayka Addis textile factory regarding the one-year and two-week prevalence which were $40.8 \%$ and $9.4 \%$, respectively [9]. However, it was higher than that of the workers in Arba Minch textile factory (31.4\%) [7], textile factories in the Amhara region $(33.3 \%)$ [10], and Kombolcha textile factory (36.9\%) [8].

In the present study, the two most injured body parts were hands $(38=12.7 \%)$ and eyes $(23=7.7 \%)$. Hand injuries may be caused by improper use of hand tools, not wearing gloves, inattention while handling sharp objects, and not following safety rules and guidelines [28], and eye injuries may be caused due to environmental conditions particularly dust particles (cotton) [29]. Hands and eyes are among the list of commonly affected body parts listed by the Ministry of Health Ethiopia [10]. In the same way, hands were among the most frequently injured body parts among workers from Arba Minch textile factory (39.7\%) [7] and Ayka Addis textile factory (21.8\%) [9] even though the prevalence of hand injuries in the present study was much lower than that in the mentioned studies. These differences may be due to differences in safety awareness, safety training, machine guards, working conditions, behavioral differences, provisions of PPEs, and nature of industries.

Monday showed the highest proportion of accidents $(4.7 \%)$ and Sunday the least (1.0\%). This may be because workers fraudulently claim that off-the-job weekend sprains and strains occurred at work on Monday [30], and a small proportion of workers are working as part-timers on Sunday. Similar findings were seen from the study conducted in Arba Minch textile factory: highest on Monday (21.3\%) and lowest on Sunday (11\%) [7].

It was observed that injuries were more common during the morning (7:00 AM-12:00 AM) (10.3\%), afternoon (1:00 PM-6:00 PM) (9.3\%), and after midnight (1:00 AM-6:00 AM) (8.7\%). However, the least cases were reported during the evening shift (7:00 PM-12:00 PM) (4.0\%). This may be due to lack of focus due to shortened sleep in the morning, rushing to go home in the afternoon, and shortened sleep after midnight [31]. The trend of injury time was in line with that of the workers from the Arba Minch textile factory [7], except that the prevalence in the present study was lower.

The bivariate regression analysis showed statistically significant differences $(p<0.05)$ in accidents due to differences in gender, job category, exposure to noise, exposure to vibration, exposure to rays/welding sparks, exposure to nonmoderate light, exposure to nonmoderate temperature, exposure to a dusty work area, prolonged work by standing 
TABle 2: Prevalence of occupational injuries among workers of Bahir Dar Textile SC, Ethiopia, April 2019.

\begin{tabular}{|c|c|c|}
\hline Variables & Number & Percent \\
\hline \multicolumn{3}{|l|}{ Injury in one year } \\
\hline Yes & 128 & 42.7 \\
\hline No & 172 & 57.3 \\
\hline \multicolumn{3}{|l|}{ Injury in two weeks } \\
\hline Yes & 20 & 6.7 \\
\hline No & 280 & 93.3 \\
\hline \multicolumn{3}{|c|}{ Frequency of occurrence injury in one year } \\
\hline Once & 59 & 19.7 \\
\hline More than once & 69 & 23.0 \\
\hline \multicolumn{3}{|c|}{$\begin{array}{l}\text { Frequency of occurrence of injury in two } \\
\text { weeks }\end{array}$} \\
\hline Once & 18 & 6.0 \\
\hline More than once & 2 & 0.7 \\
\hline \multicolumn{3}{|l|}{ Body part injured (128) } \\
\hline Eye & 23 & 7.7 \\
\hline Ear & 16 & 5.3 \\
\hline Arm & 9 & 3.0 \\
\hline Hand & 38 & 12.7 \\
\hline Head & 1 & 0.3 \\
\hline Upper leg & 1 & 0.3 \\
\hline Lower leg & 1 & 0.3 \\
\hline Tooth & 1 & 0.3 \\
\hline Anterior trunk & 1 & 0.3 \\
\hline Back & 12 & 4.0 \\
\hline Knee & 6 & 2.0 \\
\hline Toes & 14 & 4.7 \\
\hline Face & 2 & 0.7 \\
\hline Mixed & 1 & 0.3 \\
\hline Others & 2 & 0.7 \\
\hline \multicolumn{3}{|l|}{ Type of injury $(n=128)$} \\
\hline Abrasion & 32 & 10.7 \\
\hline Burn & 12 & 4.0 \\
\hline Cuts & 8 & 2.7 \\
\hline Puncture & 8 & 2.7 \\
\hline Sprain & 16 & 5.3 \\
\hline Fracture & 9 & 3.0 \\
\hline Dislocation & 5 & 1.7 \\
\hline Eye injury & 23 & 7.7 \\
\hline Ear injury & 9 & 3.0 \\
\hline Suffocation & 4 & 1.3 \\
\hline Other & 2 & 0.7 \\
\hline \multicolumn{3}{|l|}{ Causes of injury $(n=128)$} \\
\hline Machines & 68 & 22.7 \\
\hline Electricity & 3 & 1.0 \\
\hline Hand tools & 6 & 2.0 \\
\hline Explosive & 2 & 0.7 \\
\hline Acids & 5 & 1.7 \\
\hline Falling and slipping & 19 & 6.3 \\
\hline Splinter & 4 & 1.3 \\
\hline Collision & 7 & 2.3 \\
\hline Mishandling & 2 & 0.7 \\
\hline Falling objects & 4 & 1.3 \\
\hline Improper usage & 3 & 1.0 \\
\hline Others & 5 & 1.7 \\
\hline \multicolumn{3}{|l|}{ Reasons for the accident $(n=128)$} \\
\hline Lack PPEs & 59 & 19.7 \\
\hline Misuse of PPEs & 17 & 5.7 \\
\hline Disorder of normal operation & 8 & 2.7 \\
\hline
\end{tabular}

TABle 2: Continued.

\begin{tabular}{lcc}
\hline Variables & Number & Percent \\
\hline Lack of safety training & 18 & 6.0 \\
Improper hand working instrument & 13 & 4.3 \\
Absence/inadequate machine safeguards & 13 & 4.3 \\
\hline Day of injury & & \\
Monday & 14 & 4.7 \\
Tuesday & 9 & 3.0 \\
Wednesday & 7 & 2.3 \\
Thursday & 11 & 3.7 \\
Friday & 12 & 4.0 \\
Saturday & 4 & 1.3 \\
Sunday & 3 & 1.0 \\
Do not remember & 68 & 22.7 \\
\hline Time of injury ( $n=128)$ & & \\
In the morning (7:00 AM-12:00 AM) & 28 & 9.3 \\
In the afternoon (1:00 PM-6:00 PM) & 31 & 10.3 \\
In the evening (7:00 PM-12:00 PM) & 12 & 4.0 \\
After midnight (1:00 AM-6:00 AM) & 26 & 8.7 \\
Do not remember & 31 & 10.3 \\
\hline Hospitalization ( $n=300)$ & & \\
Yes & 84 & 28.0 \\
No & 216 & 72.0 \\
\hline Days lost due to injury $(n=300)$ & & \\
2-6 & 39 & 13.0 \\
7-14 & 24 & 8.0 \\
15-30 & 3 & 6.0 \\
>30 & & \\
\hline
\end{tabular}

in a limited area, exposure to biological hazards, and laborintensive work. The males were 2.38 -fold $(1 / 0.421)$ more injured than females $(\mathrm{COR}=0.421 ; 95 \% \mathrm{CI}$ : $0.253-0.700)$. Workers from the weaving section $(\mathrm{COR}=4.556 ; 95 \% \mathrm{CI}$ : $1.934-10.730)$ were 10.45 (4.556/0.439), 7.52 (4.556/0.606), $5.12(4.556 / 0.889)$, and $4.56(4.556 / 1)$ times more injured than the administrative (COR $=0.436 ; 95 \%$ CI: 0.198-0.958), finishing ( $\mathrm{COR}=0.606$; 95\% CI: 0.279-1.315), engineering $(\mathrm{COR}=0.889 ; 95 \% \mathrm{CI}: 0.419-1.887)$, and spinning (ref) staff, respectively.

From the multiple regression analysis, statistically significant differences in injuries $(p<0.05)$ were observed due to variations in gender, job category, exposure to vibration, exposure to rays/welding sparks, and labor-intensive work. The males were $3.14(1 / 0.318)$ times more injured compared with females $(\mathrm{AOR}=0.318 ; 95 \% \mathrm{CI}: 0.162-0.626)$. This finding was in line with the findings of the studies conducted in textile factories of the Amhara region [10] and textile factories in Northwest Ethiopia [11]. The difference in the levels of injury might be explained by the fact that female workers are usually assigned in less hazardous sections in textile industries and had different work schedules (the males worked relatively longer hours per day) [11, 32].

Most injuries occurred in the weaving section. The weaving section $(\mathrm{AOR}=4.497 ; 95 \% \mathrm{CI}$ : 1.557-12.990) resulted in injuries close to $8.37(4.497 / 0.537)$ times higher than the finishing staff section $(\mathrm{AOR}=0.537 ; 95 \% \mathrm{CI}$ : 0.184-1.569), 4.497 (4.497/1) times higher than the spinning (ref) staff section, $3.92(4.497 / 1.147)$ times higher than the 
TABLE 3: Risk factors and their associations with the prevalence of occupational injuries.

\begin{tabular}{|c|c|c|c|c|}
\hline \multirow{2}{*}{ Variables } & \multicolumn{2}{|c|}{ Full model } & \multicolumn{2}{|c|}{ Reduced model } \\
\hline & COR $(95 \% \mathrm{CI})$ & $p$ value & AOR $(95 \% \mathrm{CI})$ & $p$ value \\
\hline Gender & & 0.001 & & \\
\hline Male & 1.00 & & 1.00 & \\
\hline Female & $0.421(0.253-0.700)$ & $0.001^{*}$ & $0.318(0.162-0.626)$ & $0.001^{*}$ \\
\hline Age & & 0.159 & & \\
\hline $22-29$ & 1.00 & & 1.00 & \\
\hline $30-34$ & $0.841(0.485-1.458)$ & 0.537 & $0.773(0.340-1.754)$ & 0.537 \\
\hline$>34$ & $0.371(0.132-1.043)$ & 0.060 & $0.25(0.054-1.152)$ & 0.075 \\
\hline Marital status & & 0.329 & & \\
\hline Married & 1.00 & & - & - \\
\hline Single & $1.424(0.894-2.267)$ & 0.136 & - & - \\
\hline Divorced & $1.10(0.179-6.773)$ & 0.918 & - & - \\
\hline Education level & & & - & - \\
\hline No education & 1.00 & & - & - \\
\hline Primary & $0.364(0.06-2.194)$ & 0.270 & - & - \\
\hline Secondary & $1.379(0.44-4.285)$ & 0.578 & - & - \\
\hline Higher & $1.577(0.571-4.357)$ & 0.379 & - & - \\
\hline Residence & & 0.735 & - & - \\
\hline Urban & 1.00 & & - & - \\
\hline Rural & $1.407(0.195-10.121)$ & 0.735 & - & - \\
\hline Job category & & 0.000 & & 0.003 \\
\hline Spinning & 1.00 & & 1.00 & \\
\hline Weaving & $4.556(1.934-10.730)$ & $0.001^{*}$ & $4.497(1.557-12.990)$ & $0.005^{*}$ \\
\hline Engineering & $0.889(0.419-1.887)$ & 0.759 & $1.147(0.410-3.215)$ & 0.794 \\
\hline Finishing & $0.606(0.279-1.315)$ & 0.205 & $0.537(0.184-1.569)$ & 0.256 \\
\hline Administrative staff & $0.436(0.198-0.958)$ & 0.039 & $1.471(0.445-4.868)$ & 0.527 \\
\hline Employment status & & 0.506 & - & - \\
\hline Permanent & 1.00 & & - & - \\
\hline Contract & $0.462(0.468-4.497)$ & 0.506 & - & - \\
\hline Work experience & & 0.226 & & \\
\hline$<5$ years & 1.00 & & 1.00 & \\
\hline$\geq 5$ years & $0.752(0.474-1.193)$ & 0.226 & $1.061(0.550-2.046)$ & 0.861 \\
\hline Monthly salary & & 0.256 & - & - \\
\hline$<2458$ birr $(<72.00$ USD $)$ & 1.00 & & - & - \\
\hline 2459-3941 birr (72.03-115.45 USD) & $1.789(0.37-3.821)$ & 0.133 & - & - \\
\hline 3942-5776 birr (115.48-169.20 USD) & $1.306(0.602-2.834)$ & 0.499 & - & - \\
\hline$>5776$ birr $(>169.20$ USD $)$ & $2.074(0.886-4.853)$ & 0.093 & - & - \\
\hline \multicolumn{5}{|l|}{ Existence of high noise or blare } \\
\hline Yes & 1.00 & & 1.00 & \\
\hline No & $0.236(0.142-0.391)$ & $0.000^{*}$ & $0.766(0.349-1.682)$ & 0.507 \\
\hline \multicolumn{5}{|l|}{ Exposure to vibration } \\
\hline Yes & 1.00 & & 1.00 & \\
\hline No & $0.224(0.135-0.373)$ & $0.000^{*}$ & $0.419(0.199-0.878)$ & $0.021^{*}$ \\
\hline \multicolumn{5}{|l|}{ Exposure to rays/welding sparks } \\
\hline Yes & 1.00 & & 1.00 & \\
\hline No & $0.250(0.149-0.421)$ & $0.000^{*}$ & $0.366(0.167-0.799)$ & $0.012^{*}$ \\
\hline \multicolumn{5}{|l|}{ Exposure to nonmoderate light } \\
\hline Yes & 1.00 & & 1.00 & \\
\hline No & $0.439(0.270-0.715)$ & $0.001^{*}$ & $1.303(0.582-2.921)$ & 0.520 \\
\hline \multicolumn{5}{|l|}{ Exposure to nonmoderate temperature } \\
\hline Yes & 1.00 & & 1.00 & \\
\hline No & $0.432(0.269-0.693)$ & $0.001^{*}$ & $1.189(0.568-2.490)$ & 0.646 \\
\hline \multicolumn{5}{|l|}{ Exposure to chemical hazards } \\
\hline Yes & 1.00 & & & \\
\hline No & $0.663(0.390-1.127)$ & 0.129 & $0.968(0.446-2.103)$ & 0.935 \\
\hline \multicolumn{5}{|l|}{ Exposure to dusty work area } \\
\hline Yes & 1.00 & & & \\
\hline
\end{tabular}


TABLE 3: Continued.

\begin{tabular}{|c|c|c|c|c|}
\hline \multirow{2}{*}{ Variables } & \multicolumn{2}{|c|}{ Full model } & \multicolumn{2}{|c|}{ Reduced model } \\
\hline & COR $(95 \% \mathrm{CI})$ & $p$ value & AOR $(95 \% \mathrm{CI})$ & $p$ value \\
\hline No & $0.412(0.252-0.672)$ & $0.000^{*}$ & $0.937(0.409-2.148)$ & 0.878 \\
\hline \multicolumn{5}{|c|}{ Prolonged work by standing in a limited area } \\
\hline Yes & 1.00 & & 1.00 & \\
\hline No & $0.511(0.305-0.857)$ & $0.011^{*}$ & $1.039(0.515-2.099)$ & 0.914 \\
\hline \multicolumn{5}{|c|}{ Exposure to biological hazards } \\
\hline Yes & 1.00 & & & \\
\hline No & $0.531(0.326-0.863)$ & $0.011^{*}$ & $0.615(0.328-1.152)$ & 0.129 \\
\hline \multicolumn{5}{|l|}{ Labor-intensive work } \\
\hline Yes & 1.00 & & 1.00 & \\
\hline No & $0.305(0.182-0.513)$ & $0.000^{*}$ & $0.343(0.167-0.703)$ & $0.003^{*}$ \\
\hline Work supervision & & 0.148 & & \\
\hline Yes & 1.00 & & 1.00 & \\
\hline No & $0.458(0.159-1.320)$ & 0.148 & $0.335(0.077-1.450)$ & 0.143 \\
\hline Alcohol consumption & & 0.422 & - & - \\
\hline Yes & 1.00 & & - & - \\
\hline No & $0.761(0.390-1.484)$ & 0.422 & - & - \\
\hline Khat chewing & & 0.588 & - & - \\
\hline Yes & 1.00 & & - & - \\
\hline No & $0.706(0.2-2.492)$ & 0.588 & - & - \\
\hline Cigarette smoking & & 0.506 & - & - \\
\hline Yes & 1.00 & & - & - \\
\hline No & $2.163(0.222-21.038)$ & 0.506 & - & - \\
\hline Sleeping disturbance & & 0.061 & & \\
\hline Yes & 1.00 & & 1.00 & \\
\hline No & $0.643(0.406-1.021)$ & 0.061 & $0.759(0.404-1.426)$ & 0.392 \\
\hline Job satisfaction & & 0.082 & & \\
\hline Yes & 1.00 & & 1.00 & \\
\hline No & $1.561(0.944-2.581)$ & 0.082 & $0.902(0.477-1.706)$ & 0.751 \\
\hline PPE & & 0.607 & - & - \\
\hline Yes & 1.00 & & - & - \\
\hline No & $0.881(0.554-1.427)$ & 0.607 & - & - \\
\hline
\end{tabular}

COR, crude odds ratio; AOR, adjusted odds ratio; CI, confidence interval. * Statistically significant difference $(p<0.05)$.

engineering staff section ( $\mathrm{AOR}=1.147 ; 95 \% \mathrm{CI}$ : 0.410-3.215), and $3.06(4.497 / 1.471)$ times higher than the administrative staff section $(\mathrm{AOR}=1.471 ; 95 \% \mathrm{CI}$ : 0.445-4.868). However, it was different from that of Arba Minch [7] and Kombolcha [12] textile factories where such differences were not observed.

Study participants who were exposed to vibration were 2.39 (1/0.419) times more likely to be injured compared with workers who were not exposed to vibration $(\mathrm{AOR}=0.419$; 95\% CI: 0.199-0.878), workers who were exposed to rays were $2.73(1 / 0.366)$ times more likely to be injured compared with workers who were not exposed to rays $(\mathrm{AOR}=0.366$; 95\% CI: 0.167-0.799), and workers who were exposed to labor-intensive work were $2.9(1 / 0.343)$ times more likely to be injured compared with workers who were not exposed to labor-intensive work ( $\mathrm{AOR}=0.343$; 95\% CI: 0.167-0.703). Reports show that occupational exposure to vibration increases the risk of musculoskeletal pain in the back, neck, hands, shoulders, and hips [33], eye injury is associated with welding rays [34], and labor-intensive work is associated with occupational injuries [35].

\section{Conclusions}

The one-year and the two-week occupational injuries prevalence were $42.7 \%$ and $6.7 \%$, respectively. Abrasion and eye injury were the two top injuries. Hands and eyes were the top injured body parts. Machines and falling/slipping caused most injuries. Statistically significant differences in injuries were observed due to variations in gender, job category, exposure to vibration, exposure to rays/welding sparks, and labor-intensive work. The weaving section was the risk factor significantly associated with occupational injuries.

\section{Recommendations}

Establishment of occupational safety and health committees; conducting occupational safety and health training; provision of quality personal protective equipment; conducting periodic occupational and safety supervisions; shifting workers on labor-intensive works; recording and analysis of injuries; enforcement of existing laws, policies, regulations, directives, and workplace standards in the country regarding 
occupational safety, health, and work environment conditions are recommended.

6.1. Limitations. The one-year injury prevalence was conducted using questionnaires. This might lead to recall bias. The recall biases may underestimate the injury prevalence. So, the findings from this study can be generalized to the whole worker population of Bahir Dar Textile SC.

6.2. Relevance of the Findings to Public Health. The findings of this study will serve as key for intervention against occupational injuries in Bahir Dar Textile SC in particular and Ethiopia in general. It will also play a role in minimizing the psychological, behavioral, social, vocational, and economic problems of the workers.

\section{Abbreviations}

AOR: Adjusted odds ratio

CI: Confidence interval

COR: Crude odds ratio

GDP: Gross domestic product

ILO: International labor organization

PPE: Personal protective equipment

SC: $\quad$ Share company.

\section{Data Availability}

The datasets from which the conclusion was taken are available in the form of Microsoft Excel and are available on request.

\section{Conflicts of Interest}

The authors declare that they have no conflicts of interest.

\section{Authors' Contributions}

SS was involved in writing the research proposal, data collection, and data analyses. DD was involved in writing of the research proposal, data analyses, and writing of the manuscript. Both authors read and approved the final manuscript.

\section{Acknowledgments}

The authors would like to thank the workers and administrative personnel of the Bahir Dar Textile SC for their cooperation during data collection.

\section{References}

[1] FDRE, Growth and Transformation Plan II (GTP II) (2015/ 16-2019/20), National Planning Commission, Addis Ababa, Ethiopia, 2016.

[2] M. Karvonen, M. Mikheev, and WHO, Epidemiology of Occupational Health, World Health Organization Regional Office, Geneva, Switzerland, 1986.

[3] S. Tadesse and D. Israel, "Occupational injuries among building construction workers in Addis Ababa, Ethiopia,"
Journal of Occupational Medicine and Toxicology, vol. 11, no. 1, p. 16, 2016.

[4] E. Nordberg, "Injuries as a public health problem in subSaharan Africa: epidemiology and prospects for control," East African Medical Journal, vol. 77, no. 12, pp. S1-S43, 2000.

[5] L. I. Boden, E. A. Biddle, and E. A. Spieler, "Social and economic impacts of workplace illness and injury: current and future directions for research," American Journal of Industrial Medicine, vol. 40, no. 4, pp. 398-402, 2001.

[6] P. Hämäläinen, J. Takala, and T. B. Kiat, "Global Estimates of Occupational Accidents and Work-Related Illnesses 2017," World, vol. 2017, pp. 3-4, 2017.

[7] G. Gebremichael, A. Kumie, and D. Ajema, "The prevalence and associated factors of occupational injury among workers in Arba Minch textile factory, southern Ethiopia: a cross sectional study," Occupational Medicine and Health Affairs, vol. 3, no. 6, Article ID e1000222, 2015.

[8] S. S. Yessuf, H. G. Moges, and A. N. Ahmed, "Magnitude and characteristics of occupational injury in Kombolcha textile factory, North East Ethiopia," International Journal of Occupational Safety and Health, vol. 3, no. 2, pp. 25-29, 2013.

[9] J. Musa, Assessment of Occupational Injury and Associated Factors Among Workers of Ayka Addis Textile Factory in Sebeta, Oromia Region, Ethiopia: Institutional-Based Cross Sectional Survey, Addis Ababa University, Addis Ababa, Ethiopia, 2019.

[10] Z. Aderaw, D. Engdaw, and T. Tadesse, "Determinants of occupational injury: a case control study among textile factory workers in Amhara Regional State, Ethiopia," Journal of Tropical Medicine, vol. 2011, Article ID 657275, 8 pages, 2011.

[11] S. D. Wami, D. H. Chercos, A. Dessie et al., "Cotton dust exposure and self-reported respiratory symptoms among textile factory workers in Northwest Ethiopia: a comparative cross-sectional study," Journal of Occupational Medicine and Toxicology, vol. 13, no. 1, p. 13, 2018.

[12] S. Y. Serkalem, G. M. Haimanot, and N. A. Ansha, "Determinants of occupational injury in Kombolcha textile factory, north-east Ethiopia," International Journal of Occupational and Environmental Medicine, vol. 5, no. 2, pp. 84-93, 2014.

[13] J. Kim, "Depression as a psychosocial consequence of occupational injury in the US working population: findings from the medical expenditure panel survey," BMC Public Health, vol. 13, no. 1, p. 303, 2013.

[14] K.-H. Lin, J. S.-C. Shiao, N.-W. Guo et al., "Long-term psychological outcome of workers after occupational injury: prevalence and risk factors," Journal of Occupational Rehabilitation, vol. 24, no. 1, pp. 1-10, 2014.

[15] R. Gammarano, "Occupational injuries: ILO department of statistics," in 20th International Conference of Labour Statisticians 10-19 October 2018, pp. 167-169, International Labour Organization, Geneva, Switzerland, 2018.

[16] B. D. T. S. Company, "Background and History-Bahir Dar Textile Share Company," 2020.

[17] TFO-Canada, "Bahir dar textile share company, Ethiopia," 2016, https://www.tfocanada.ca/supply.php?item $=12750$ \& theiso $=$ ET\&linkcount $=\&$ thepage $=1$ \&searchtype $=2$ \&indgroup $=$ \&supplycount=Ethiopia\&search $=$ Search.

[18] CIA, "Ethiopia economy 2020, in countries of the world," 2020, https://theodora.com/wfbcurrent/ethiopia/ethiopia_economy. html.

[19] G. Guercia, ILO calls for urgent global action to fight occupational diseases, Geneva, 2013,https://www.ilo.org/global/ about-the-ilo/newsroom/news/WCMS_211627/lang--en/index. htm. 
[20] Assolombarda, "Bahir Dar textile share company's profile," 2020, https://www.assolombarda.it/fs/200498175949_78.pdf/.

[21] Wikihow, "How to Calculate Sample Size," 2019, https://www. wikihow.com/Calculate-Sample-Size.

[22] ILO, "Resolution concerning statistics of occupational injuries (resulting from occupational accidents), adopted by the Sixteenth International Conference of Labour Statisticians," in The Sixteenth International Conference of Labour Statisticians, Geneva, Switzerland, October 1998, http://ilo.org/ wcmsp5/groups/public/---dgreports/---stat/documents/ normativeinstrument/wcms_087528.pdf.

[23] H. Mulugeta, Y. Tefera, and M. Gezu, "Nonfatal occupational injuries among workers in microscale and small-scale woodworking enterprise in Addis Ababa, Ethiopia," Journal of Environmental and Public Health, vol. 2020, Article ID 6407236, 8 pages, 2020.

[24] B. Aziri, "Job satisfaction: a literature review," Management Research \& Practice, vol. 3, no. 4, 2011.

[25] O. S. H. Matters, "Tag archives: biological hazards," 2020, https://oshmatters.wordpress.com/tag/biological-hazards/.

[26] Y. Masnita and S. V. Riorini, "Recovery emotions on perceived justice," Jurnal Manajemen Dan Pemasaran Jasa, vol. 11, no. 2, pp. 161-176, 2018.

[27] K. Feder, D. Michaud, J. McNamee, E. Fitzpatrick, H. Davies, and T. Leroux, "Prevalence of hazardous occupational noise exposure, hearing loss, and hearing protection usage among a representative sample of working Canadians," Journal of Occupational and Environmental Medicine, vol. 59, no. 1, pp. 92-113, 2017.

[28] J. Hoffmann, "Preventing hand injuries in the manufacturing sector," 2015, https://www.hoffmannworkcomp.com/preventinghand-injuries-in-the-manufacturing-sector/.

[29] J. M. Leung-Heras, "Stories from the front: health care access in the us and Mexico in Mexican migrant farm workers," M.S. thesis, The University of Iowa, Iowa City, IA, USA, 2010.

[30] M. Poland, I. Sin, and S. Stillman, "Why are there more accidents on Mondays? economic incentives, ergonomics or externalities," 2020.

[31] J. Violanti, "Shifts, extended work hours, and fatigue: an assessment of health and personal risks for police officers," 2012, https://www.ncjrs.gov/pdffiles1/nij/grants/237964.pdf.

[32] A. Lette, M. Kumbi, A. Hussen, and S. Nuriye, "Determinants of occupational injury among building construction employees in southeastern Ethiopia," International Journal of Tropical Disease \& Health, vol. 34, no. 4, pp. 1-11, 2018.

[33] K. Krajnak, "Health effects associated with occupational exposure to hand-arm or whole body vibration," Journal of Toxicology and Environmental Health, Part B, vol. 21, no. 5, pp. 320-334, 2018.

[34] D. A. Lombardi, R. Pannala, G. S. Sorock et al., "Welding related occupational eye injuries: a narrative analysis," Injury Prevention, vol. 11, no. 3, pp. 174-179, 2005.

[35] M. Kebede, "Assessment of knowledge, attitude \& practice towards safety measures among workers in FDRE metal \& engineering corporation Metec," M.S. thesis, Addis Ababa University, Addis Ababa, Ethiopia, 2014. 